\author{
Andrzej Jastrzębski OMI ${ }^{1}$ \\ 0000-0003-2637-7706 \\ Saint Paul University, Canada
}

\title{
Towards an Adequate Anthropology ${ }^{2}$
}

What is an adequate anthropology? It is an anthropology that sees each human being as a person. It reveals fully our complexity and our fascinating dignity as humans. 'Adequate anthropology' is a term proposed by John Paul II and based on three sources: The Bible, theology, and philosophy. Generally speaking, its aim consists in the defense and safeguard of a large and holistic concept of our existence in opposition to all contemporary reductionistic accounts. Sketching an adequate anthropology appears to be both a huge challenge and a research program without clear boundries. However, this endeavour is not a new one. It is as old as Western civilization if we accept that European culture began in ancient Greece. At Delphi, the visitors to the temple of Apollo were told to "know thyself!" (gnōthi

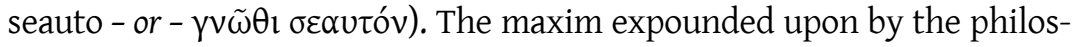
opher Socrates, and this is what an adequate anthropology is aiming at.

1 Andrzej Jastrzębski OMI - holds a post-gradual diploma in Pastoral Counseling, a PhD in Philosophical Anthropology, and a habilitation in spiritual theology. He authored several books, number of articles on anthropological issues bordering spirituality, philosophy and psychology. E-mail: andrzej.jastrzebski@oblaci.pl.

2 This article has been inspired by the lecture delivered by prof. Rocco Buttiglione during his doctorate honoris causa ceremony at the Catholic University of Lublin on May $18^{\text {th }} 1994$.

3 The author of the term "adequate anthropology" is St John Paul II. He used it in his catechesis: Mężczyzną i niewiasta stworzył ich, Vaticanum 1986, s. 54-55. An adequate anthropology describes our existence in essentially human, rather than reductionist, terms. 
Without doubt, modern times have seen huge developments in the sciences of human nature. Within the humanities, social sciences, and natural sciences, new disciplines have emerged, bringing abundant discoveries to bear on the study of human nature. Each having specific goals and methodologies, they complement each other in the understanding of their ultimate object.

Nevertheless, we have to keep in mind that every individual is unique, and can be studied by different sciences: biology, medicine, physics, natural anthropology, ethnology, sociology, psychology, etc. Philosophical anthropology aims at studying the human being as a specific type of being, considering the global configuration and the totality of our very personhood. This leads it to describe the essential traits that constitute the uniqueness of our existence.

Developing an adequate anthropology will enable us to discover the very truth about ourselves. While considering the results of scientific research, it never loses sight of revelation. It is through revelation that the Creator of our being gives us the best insights into ourselves.

\section{Limited scientific competences}

Experts in contemporary physics and chemistry have received much praise due to their competent work and above all for their efficiency in mastering nature. Their coming to represent the pinnacle of knowledge, and their challenge to established authority, are tied up in a rather complex way with the perennial temptations in dealing with the question of human nature. Yet, there is, in the natural sciences, little room for those essential questions. Philosophers and theologians, who for centuries have reflected on the meaning of life and the destiny of the human being, have been relegated to the margins of science. Instead, we have scientists trying to extend the authority of natural and experimental science whose goal is to tell us what the meaning of our life should be. ${ }^{4}$

4 Por.A.Jastrzębski, Homo theomorphicuset theophoricus. Studium zreceptywno-responsywnej teorii duchowości, Lublin 2015. 
Questions regarding the meaning of life should not be the domain of physicists or chemists. These questions are perhaps a little bit more appropriate for biology, since it has interest in the beginning and development of life as well as its definition. Undoubtedly, every science dealing with human life will have something implicite - and sometimes explicite - to say about the origin and meaning of human life. We need to bear in mind the limits of natural sciences when evaluating the field of competence of each discipline. The careless acceptance of any 'scientific' view which maintains that we are a byproduct of entropy begs the question in favour of an authentic ontological concept that needs sound justification. One can similarly challenge the thesis that human beings are either the products of inner impulses or of the external environment, or again, the thesis that consciousness is only a function of the nervous system and byproduct of evolution.

We transcend our own nature, since we are in constant search of values and meaning; we are dialogical beings, always placing ourselves in relation to Someone who is the Source of that being. The human being is a personal being, a bio-psycho-spiritual entity. ${ }^{5}$

Wojtyła offers an excellent synthetic view of the task of an adequate anthropology:

But certain questions always remain: Are these two types of understanding the human being - the cosmological and the personalist - ultimately mutually exclusive? Where, if at all, do reduction and the disclosure of the irreducible in the human being converge? How is the philosophy of the subject to disclose the objectivi ty of the human being in the personal subjectivity of this being? These seem to be the questions that today determine the perspective for thinking about the human being, the perspective for contemporary anthropology and ethics. They are essential and burning questions. Anthoropology and ethics must be pursued within this challenging but promising perspective. ${ }^{6}$

${ }^{5}$ K. Popielski, Logoteoria i logoterapia w kontekście psychologii współczesnej, w: Człowiek pytanie otwarte. Studia z logoteorii i logoterapii, red. K. Popielski, Lublin 1987, p. 29.

6 K. Wojtyła, Person and Community. Selected Essays, transl. T. Sandok, New York 1993, s. 216; M. Chmielewski, Ciało a duchowość. Zarys problematyki, "Ethos" (4) 2008, p. 47-57. 


\section{Christ-oriented anthropology}

An adequate anthropology in its theological dimension needs to be viewed in the light of the Incarnation, the Incarnate Word, Jesus Christ, who has shown us what it means to be a perfect human being. ${ }^{7}$ Moreover, an adequate anthropology has to grasp every being, and particularly every human being, in a dynamic way. The question of the meaning of our existence is simultaneously one of its development and our history. ${ }^{8}$

We propose that an adequate anthropology have both philosophical and theological foundations in order to grasp the essence of humanity. This being said, we have to remember that the focal point of theological anthropology is the divine act of creation, while some philosophical anthropologies do not consider this. ${ }^{9}$ In the following, we shall examine certain examples of the latter.

In a neo-Platonic perspective, the main goal of our lives is to return to God, to be united with Him. Every act of purification of the soul can foster this process, by leading the soul to become a "god," i.e. to recover its pure identity. The Platonic viewpoint conflicts in many ways with Christian anthropology, which underlines God's transcendence and personality. In Plato's perspective, God is not a person, and even the personhood of our own self is only provisory. The appearance of humanity in the world is ever-changing. In the Bible, God is quite gladdened to have created us, whereas Platonic authors see our coming to this world as both our fall and punishment. Also, matter, in the Platonic perspective, has no independent existence and is only a manifestation of the emanative process. ${ }^{10}$ The link between being and matter is perceived negatively. In the Christian perspective, God is a person and the

\footnotetext{
A. J. Nowak, Osoba. Fakt i tajemnica, Rzeszów 2010, p. 50.

A. J. Nowak, Osoba. Fakt i tajemnica, op. cit., p. 51.

9 M. Grabowski, Historia upadku, ku antropologii adekwatnej, Kraków 2006, p. 16.

10 Aquinas taught that the creation of the world from nothing depends on the "emanation of all being from the universal cause, which is God' (The Collected Works of St. Thomas Aquinas. Electronic Edition. Summa Theologiae, transl. Fathers of the English Dominican Province, Charlottesville 1993, I, q. 45, a. 1), and 'from which emanation matter itself is not excluded' (I, q. 44 ad 1).
} 
human being is another person progressing toward God. We never lose ourselves in God, never have to abandon our distinctiveness. Uniting with God does not mean that God absorbs us; God, justly, is respectful of our human development, including the materiality that affects every aspect of our personal existence - since God is the creator of everything that exists. Another difference concerns the image of God within the human being. For Platonic thinkers, our existence is a microcosm, a mirror of the whole world, in which divine and human elements are interwoven. For Christian thinkers however, the image of God within the human being is located in the soul, in the mind (nous). It is the divine spark. The journey of spiritual purification leads this spark to reflect on its source. Another difference between Platonism and Christianity lies in the way God can be encountered. For the ancient Greeks, the encounter with God has to be accomplished through a process of becoming like God, whereas the Bible teaches that God will reveals Himself to us. When God communicates Himself to us, we are much closer to knowing ourselves since we are created in His image and likeness. In Platonism, we come to know God through the endeavour of better self-understanding, but in Christianity God communicates Himself to us. ${ }^{11}$

\section{Holistic anthropology}

Today, in a period often depicted as postmodern, anthropology in itself has not received serious reflection. We use an abundance of surveys of diverse types to study the human condition. This research takes place in several different disciplines such as psychology, sociology, politology, to name but a few, but neglects the integral image of the human being. Each of these scientific disciplines comes with a specific, yet reductionist, concept of the human being. For centuries, in the humanities and social sciences, we have had reductionist concepts of ourselves and the evolutionary view of morality. This is not useful, as evolution leaves no room for stable, ultimate values: they become no more than by-products of the

11 L. Bouyer, Introduction to Spirituality, transl. M. P. Ryan, New York 1961, p. 144-148. 
struggle to survive. None of these disciplines - whether biology, sociology, or psychology - can develop a proper philosophy of life, because they do not address the ontology of human life and are influenced by the scientific bias of statistical methods. ${ }^{12}$

Emerging from this scientific ideology is a new and secularized anthropology that dismisses our communal nature. It conceives of us as the products of various processes including socialization, evolution, technology, or "personal" choices. ${ }^{13}$ On the contrary, it is more accurate to say that humanity is the imago Dei, a spiritual being, who cannot be reduced to an animal, even the most developed one.

A negative anthropology leads to nihilism ${ }^{14}$ which reduces us to a series of accidental causes. Negativity here lies in the reductionism of human existence to the processes of nature, and the failure to define what should be seen as right and what should be considered wrong. We need an appropriate anthropology to secure our rightful, transcendental dignity. The current stage in history should ignite reflections on how to correct this incoherent vision of our lives. Fortunately, many attempts are being made to rectify this erroneous conception.

The evolutionary concept of human life contains the same flaws that plague the theory of evolution itself. Even though human nature is dynamic and changing, it has little in common with evolution. Its dynamism is more the result of freedom than naturalistic determinism. ${ }^{15}$ The paleontologist, Niles Eldredge, recognizes that, from the standpoint of the natural sciences, we have neither an argument for the theory of evolution nor a clear view of the origin of life. ${ }^{16}$

From the perspective of psychology, the human being remains a very small fragment of the world. This type of thinking is "anthropological transcendentalism" (if not subjective idealism). It studies the transcendental human being, a philosophical construct. The real, living human

12 N. Berdyaev, The Destiny of Man, London 1945, p. 20-21.

13 V. Possenti, L'Ouomo postmoderno, Genova-Milano 2009, s. 109. Unfortunately, this anthropology is taken to supply the basis for informing politics and education.

14 R. Buttiglione, Towards an adequate anthropology, "Ethos" (2) 1996, p. 237-246.

15 N. Berdyaev, The Destiny of Man, op. cit., p. 52.

16 A. J. Nowak, Osoba. Fakt i tajemnica, op. cit., p. 49-50. 
being cannot be manipulated artificially for the sake of science - as proposed by Edmund Husserl with his phenomenological method. Every attempt to objectify our nature blocks any adequate contact with ourselves, because it is only through contact and communion that one can really see and understand a person. ${ }^{17}$

Take psychotherapy, for example. It is always built on a specific worldview which provides a better or worse picture of our existence and personality. We have an empty, meaningless vision of ourselves in this scientific realm dominated by the Machine Model or the Rat Model (Allport). ${ }^{18}$

The truth is that the human being is neither solely the transcendental self nor is it reducible to a succession of mental events. Epistemology establishes our status as mere objects of knowledge and leaves the rest to psychology or sociology. Yet we can only know ourselves from the point of view of ontology and spirituality. Otherwise, if perceived exclusively from the standpoint of psychology or sociology, we become incomprehensible to ourselves. ${ }^{19}$

According to Emmanuel Mounier, the human being is equally a spiritual and a material entity. By this, he means that we're neither simply a body (materialism) nor simply a soul (angelism). Life experience brings us to recognize these interwoven dimensions of our existence. ${ }^{20}$ We can say in more philosophical terms that, even though our spiritual life is always associated with corporeal reality, both cognition and love are expressions of our spirituality. The spiritual life is the essence of our existence, as a "borderline case" (or a "liminal case"), as an entity full of tension between the limitations of matter and the freedom of the spirit. This tension incites us to transcend ourselves and to journey towards the wholeness of our being. We are conscious of being a part of this world, as well as different from it. Through intellectual knowledge and love, we clearly transcend the natural world. ${ }^{21}$

\footnotetext{
17 N. Berdyaev, The Destiny of Man, op. cit., p. 8-9.

18 V. E. Frankl, The Will to Meaning. Foundations and Applications of Logotherapy, New York 1988, p. 15-16.

19 N. Berdyaev, The Destiny of Man, op. cit., p. 10.

20 E. Mounier, Manifesto al servizio del personalismo comunitario, Cassano 1975, p. 65-66.

21 Z. Zdybicka, Człowiek i religia, Lublin 1993, p. 164-165.
} 
Without the ability to self-transcend, we risk reducing ourselves to mere minds without love, because intellectual knowledge brings the possibility of treating ourselves as objects or even as inferior animals. The spiritual soul constitutes the human person. That is why we cannot fully explain spirituality within the categories of biology or psychology alone. As spiritual beings, we express ourselves through our personalities and spiritual deeds. Our ultimate fulfillment is Jesus Christ - that is, in truth, goodness, happiness, freedom, and love. ${ }^{22}$

Hans Urs von Balthasar proposes that, to understand human existence, it is necessary to consider the meaning of life. Yet, it is possible to see our role in the cosmos as one of fundamental questioning, and, on this basis, develop an anthropology with little concern for the ultimate meaning of life as such, but rather for the questioning being itself. This being is capable of questioning its very existence, here and now, and as a result, of questioning existence in general. But it is only after establishing such questioning that the shift from natural anthropology to a holistic one may occur. Many forms of psychoanalysis (Freud, Jung, Adler) have remained branches of the same introspective psychological tradition that tried to reduce the question of meaning to a more psychological one. By no means, however, has it considered the meaning of existence. In this it differs from Frankl's logotherapy in which the recovery of the person depends on this type of questioning. ${ }^{23}$

\section{Metaphysical Anthropology}

The human sciences have become highly specialized. The proof of this is the number of subdisciplines concentrating on various aspects of human nature. When it proves impossible to grasp some specific aspect for instance the occurrence of self-consciousness - a dangerous pattern emerges of acknowledging or denying our "personhood" altogether.

22 A. J. Nowak, Osoba. Fakt i tajemnica, op. cit., p. 241.

${ }^{23}$ H. U. von Balthasar, Epilogue, transl. E. T. Oakes, San Francisco 2004, p. 20-21; see: H. Sławiński, Preaching. An aid to the search for the meaning of life, "The Priest" 6 (2015), p. 47-48. 
To have a full picture of the human being we need the philosophical part of an adequate anthropology. A distinctive dimension of metaphysical anthropology consists in this: the human condition is not considered from a specialized point of view. Philosophical anthropology nonetheless needs something definitive and concrete as a starting point. A key principle here is one taken from general metaphysics which opposes the authenticity of vague or contradictory statements in reference to our nature.

To achieve a clear understanding, one first needs to get to know and describe the reality of the human being correctly, as someone's reality, to which we have acces phenomenologically, from the perspective of lived experience. Although we cannot ignore the data gathered by the natural sciences, it must be recognized that they often trade in ad hoc hypotheses, selected facts, mathematical models, or just plain idealizations that only approximate reality. Also, the sciences today rest mainly on quantitative and measurable aspects of things. Since such theories are generally erected on the principle of prima facie inference, they need to be received with great care. Philosophical anthropology is a distinct science that aims at remaining in the realm of solid conclusions, and has developed its own conceptual apparatus and methodology.

We do not have scientific knowledge of the self. We can only have such knowledge indirectly, through our actions. Only when we discover that many of our actions have an immaterial source, do we further see this dimension of the self. In this instance, we can only "feel" it; this approach to the discovery of the self is through the "intuition of being" ${ }^{24}$

According to Aristotle and Thomas Aquinas, there is no way for us to get to know someone directly, and completely. Even when we become aquainted with someone, we see only their generic characteristics. Only God has an immediate integral knowledge of our nature because only Good knows all dimensions of our being. The Christian tradition distinguishes between the partial knowledge we have on earth ("as if in a glass darkly", 1 Corinthians 13:12) and the more complete one we will have after death. The substantial form that connects all of us is the same

24 J. Maritain, A Maritain reader; selected writings. Edited with an introduction by Donald and Idella Gallagher, Garden City 1966, p. 78-90. 
for every human being; what distinguishes us one from another is the matter that this form comes to and moulds - but above all, this distinguishing factor is the singular act of existence received as a gift from our Creator. This kind of reflection on the human being can only find its fulfilment in the field of theology.

\section{Theological anthropology}

The Christian theological conception of human existence has its source in revelation. Other sciences of humankind lack this advantage, simply because they are developed through the natural capacities of the human intellect. ${ }^{25} \mathrm{As}$ it articulates an answer to the existential questions, the meaning of life, the anthropology of the Incarnation surpasses philosophical anthropology. It leads to an understanding of the dignity and value of the human person, grounded in the incarnate Word of God. ${ }^{26}$

The Fathers of the Church have not left us with comprehensive teachings in regard to anthropology. Gregory of Nyssa stands alone with his treatise On the Making of Man. ${ }^{27}$ The most pressing question for the fathers pertained to the relationship of the soul to the body. The carnality of the person has been the object of many reproaches throughout history. Already Plato understood the body as a prison for the soul. In the Christian tradition, the body was initially created as "good." But the human being decided to reject God, which we describe in theology as sin, and thus human fate was sealed, which was transalted into the conflict of the soul with the body. This was never a part of the divine intention, though it may have been in the plan of God's providence. ${ }^{28}$

The true understanding of our existence cannot come from our earthly nature but needs to involve the reality of God's act of creation.

25 K. A. Wojcieszek, Na początku była rozpacz... Antropologiczne podstawy profilaktyki, Kraków 2005, p. 94.

26 A. J. Nowak, Osoba. Fakt i tajemnica, op. cit., p. 240.

27 P. Evdokimov, Woman and the Salvation of the World, transl. A. P. Gythiel, Crestwood 1994 , p. 31.

${ }^{28}$ L. Bouyer, Introduction to Spirituality, op. cit., p. 145-146. 
In Christianity, it is crucial to our self-actualization to undergo union with God through love. This union is fulfilled in a supernatural order and is a gift from God. This dimension of spiritual experience infinitely surpasses the realm of nature, even if the latter is presupposed by it.

The path to union with God opens itself to us in a mysterious way. This union only happens within a relationship to God, but one that we often misunderstand, see as remote, or ignore altogether. However, this relationship is fundamental to our spiritual development. One cannot fully grasp the essence of our spirituality without its supernatural dimension, i.e. it must be considered in relation to soteriology, the eternal joy of the human person, the personal and intimate encounter with the loving God. This only happens at the level of theological anthropology.

\section{Conclusions}

Each scientific concept of our existence - the anthropological, sociological, and psychological perspectives - offers its own grain of truth. They tell us that the human being is a rational being, motivated by values; our bodies are condemned to ephemerality, and we suffer from conflicts between the id, the ego, and the superego. Yet, none of these concepts can grasp the substance of our experience. Christian anthropology, which considers the entirety of our existence - our beginning and our destiny - is the only type of anthropology that adequately understands our existence.

The following statements form the basis of Christian anthropology:

- We were created in the image and likeness of God;

- God became a man: Jesus, the son of God, appeared before us as a human being;

- We have been called to serve and work in cooperation with the Creator;

- The human being is not merely a sinner, not merely a social animal, not merely a locus of interior (unconscious) conflicts but, first and foremost, a creative being. ${ }^{29}$

\footnotetext{
29 N. Berdyaev, The Destiny of Man, op. cit., p. 53.
} 
The narrative of creation is an anthem to the glory of God, but also to the glory of humanity, since we bear in ourselves the image and likeness of God. The human person is and will remain a mystery, because it has in itself a reflection of God's mystery. The human being is elevated by God above all of creation, as we are the image of God in the world. In an amazing way, God and the human being illuminate each other, and a humanistic understanding of our existence, lacking this mutual commitment strips us of our greatest profundity. Left alone, we begin to take a negative view of ourselves, for instance, by thinking that we are merely an accident of evolution. Yves Congar concludes even more boldly that there can be no philosophical anthropology that is not Christian and mystical, because we have no established nature outside of the image of God, or even of the entire Holy Trinity. This pertains especially to Eastern Christianity. ${ }^{30}$

Theological anthropology is committed to a conception of the human being as a dynamic entity, who intrinsically carries the image and likeness of the Creator. This establishes the premise of our individual freedom. It makes us spiritual, capable of rising above nature and of mastering it, even though after the first sin we became divided in ourselves and now desperately desire wholeness. ${ }^{31}$ Although God is revealed throughout the entire universe, it is only in our own nature that God is revealed as an image.

An intuitive knowledge of our spirituality is essential to our existence, a constitutive element of human nature. The science of our nature must involve not only the material but also the religious and moral features of our existence, including our eternal destiny. With the help of revelation, Christian anthropology is more complete than either a naturalistic or humanistic understanding of ourselves.

To have value and to be blessed, a life must have a meaning. Meaning is not a by-product of natural processes, even those of the highest quality, but something that stands beyond them. We have to acknowledge the difference between a true life and a false and failed one. Life reaches its

30 Y. Congar, Człowiek i przebóstwienie w teologii prawosławnej, “Znak” 20 (1968), p. 844.

31 W. Stinissen, Człowiek prawdziwy, Poznań 2013, p. 49. 
apogee when it relates to something greater than itself. This implies that life can be interpreted equally in terms of biology or in terms of spirituality. The spiritual elevation to God, to a life with God, constitutes the highest value we can achieve. A spiritual life does not stand in opposition to, nor does it imply the destruction of the intellectual or biological. On the contrary it brings them to a higher level. An adequate anthropology will be an ascending anthropology that starts by reflecting on our existential situation, especially of our corrupt nature, which is the splintering of God's image in us. Among others, St. Augustine decided to follow such an existential path. This kind of anthropology begins with the first sin and ends with the incarnate Word as the model of full personhood. 


\section{Summary}

\section{Towards an Adequate Anthropology}

An adequate anthropology is an anthropology that sees each human being as a person. It reveals fully our complexity and the fascinating dignity of human beings. 'Adequate anthropology' is a term proposed by John Paul II and based on three sources: The Bible, theology, and philosophy. Generally speaking, its aim consists in the defense of a large and holistic concept of our existence in opposition to all contemporary reductionistic accounts. Developing an adequate anthropology enables us to discover the very truth about ourselves. While considering the results of scientific research, it never loses sight of revelation. It is through revelation that the Creator of our being gives us the best insights into ourselves. An adequate anthropology begins by reflecting on our existential situation, which is the splintering of God's image in us, and ends with the incarnate Word as the model of a perfect personhood.

Keywords: person, holistic anthropology, science and theology

\section{W kierunku adekwatnej antropologii}

Antropologia adekwatna jest antropologią, która postrzega każdą istotę ludzką jako osobę. Ujawnia ona w pełni złożoność i niezwykłą godność człowieka. 'Antropologia adekwatna' to wyrażenie zaproponowane przez Jana Pawła II i oparte na trzech źródłach: Biblii, teologii i filozofii. Ogólnie rzecz biorąc, jej celem jest obrona holistycznej koncepcji naszego istnienia w opozycji do wszystkich współczesnych podejść redukcjonistycznych. Rozwijanie antropologii adekwatnej pozwala nam odkryć prawdę o nas samych. Rozważając wyniki badań naukowych, nigdy nie traci z oczu Objawienia. To właśnie poprzez Objawienie Stwórca naszej istoty umożliwia nam najlepszy wgląd w nas samych. Antropologia adekwatna rozpoczyna się od refleksji nad naszą sytuacją egzystencjalną, która jest zniekształceniem Bożego obrazu w nas, a kończy na Wcielonym Słowie, które jest obrazem doskonałego bycia człowiekiem.

Słowa kluczowe: osoba, antropologia holistyczna, teologia i nauka

\section{Bibliography}

Berdyaev N., The Destiny of Man, London 1945.

Bouyer L., Introduction to Spirituality, transl. M. P. Ryan, New York 1961.

Buttiglione R., Towards an adequate anthropology, "Ethos" 2 (1996), p. 237-246. 
Chmielewski M., Ciało a duchowość. Zarys problematyki, "Ethos" 4 (2008), p. 47-57.

Congar Y. , Człowiek i przebóstwienie w teologii prawosławnej, "Znak" 20 (1968), p. 844-864.

Evdokimov P., Woman and the Salvation of the World, transl. A. P. Gythiel, Crestwood 1994.

Frankl V. E., The Will to Meaning. Foundations and Applications of Logotherapy, New York 1988.

Grabowski M., Historia upadku, ku antropologii adekwatnej, Kraków 2006.

Jastrzębski A., Homo theomorphicus et theophoricus. Studium z receptywno-responsywnej teorii duchowości, Lublin 2015.

Jan Paweł II, Mężczyzną i niewiastą stworzył ich, Vaticanum 1986.

Maritain J., A Maritain reader; selected writings. Edited with an introduction by Donald and Idella Gallagher, Garden City 1966.

Mounier E., Manifesto al servizio del personalismo comunitario, Cassano 1975.

Nowak A. J., Osoba. Fakt i tajemnica, Rzeszów 2010.

Popielski K., Logoteoria i logoterapia w kontekście psychologii współczesnej, w: Człowiek - pytanie otwarte. Studia z logoteorii i logoterapii, red. K. Popielski, Lublin 1987, p. 27-65.

Possenti V., L'Ouomo postmoderno, Genova-Milano 2009.

Sławiński H., Preaching. An aid to the search for the meaning of life, "The Priest" 6 (2015), s. 47-51.

Stinissen W., Człowiek prawdziwy, Poznań 2013.

The Collected Works of St. Thomas Aquinas. Electronic Edition. Summa Theologiae, transl. Fathers of the English Dominican Province, Charlottesville 1993.

Von Balthasar H. U., Epilogue, transl. E. T. Oakes, San Francisco 2004.

Wojcieszek K. A., Na początku była rozpacz... Antropologiczne podstawy profilaktyki, Kraków 2005.

Wojtyła K., Person and Community. Selected Essays, transl. T. Sandok, New York 1993. Zdybicka Z., Człowiek i religia, Lublin 1993. 